Paedagogia Christiana

I/27 (20I I) - ISSN 1505-6872

Mariola Teresa Kozubek ${ }^{*}$

Katowice

\title{
Dialog międzyreligijny w życiu i dzialalności Ruchu Focolari
}

Dialog międzyreligijny, jako wydarzenie społeczne i religijne, stał się faktem na przełomie XX i XXI wieku. Podkreśla się jego wartość i potrzebę, zwłaszcza w środowiskach wielokulturowych i wieloreligijnych Europy. Zdaniem Jana Pawła II, dialog międzyreligijny „stanowi jedno z najważniejszych wyzwań naszej epoki" ". Czym jednak jest w swej istocie dialog międzyreligijny? Jaki jest jego cel? Co stanowi jego podstawę? Jakie są jego przejawy? Odpowiedzi na postawione pytania postaram się udzielić w oparciu o analizę doświadczenia katolickiego Ruchu Focolari na płaszczyźnie dialogu międzyreligijnego (wł. Movimento dei Focolari).

Zagadnienie zostanie zaprezentowane w trzech częściach. W pierwszej części, przedstawiając $\mathrm{w}$ zarysie fundamenty dialogu międzyreligijnego, ukażę najbardziej podstawowe ujęcie tego dialogu przez Kościół katolicki oraz powszechną normę etyczną wyrażoną w świętych księgach wielkich religii, W formie tak zwanej «złotej zasady». W części drugiej zaprezentuję podstawy dialogu międzyreligijnego w Ruchu Focolari, natomiast w części trzeciej ukażę owoce, będące wynikiem praktycznego wymiaru tegoż dialogu.

* Dr Mariola Teresa Kozubek jest wykładowcą pedagogiki na Wydziale Teologicznym Uniwersytetu Śląskiego w Katowicach. Jest członkiem Rady Wspólnej Katolików i Muzułmanów. W latach 2007-2009 prowadziła prace badawcze na temat działalności wychowawczej Ruchu Focolari w Europie (Włochy, Niemcy), Afryce (Kamerun) i Ameryce Południowej (Argentyna, Urugwaj).

1 Jan Paweł II, Migracje a dialog międzyreligijny (Orędzie Ojca Świętego na Światowy Dzień Migranta 2002 r.), „L'Osservatore Romano” 4 (2002), s. 5. 


\section{Fundamenty dialogu międzyreligijnego}

Pojęcie «dialog» (grec. diálogos - rozmawiać) w podstawowym znaczeniu kojarzy się z debatą czy rozmową, w wyniku której dochodzi do ustalenia wspólnego stanowiska osiagnniętego na drodze pertraktacji, negocjacji i ustępstw dokonanych przez każdą ze stron, czyli na drodze kompromisu². Jest ono przedmiotem wielopłaszczyznowej refleksji na gruncie filozofii, teologii i nauk społecznych. Dla potrzeb tego studium koncentruję swoją uwagę na znaczeniu dialogu w wymiarze relacji międzyreligijnych i na tej płaszczyźnie ukazane wyżej powszechne rozumienie dialogu może rodzić problemy. Fakt, że „Kościół nie odrzuca niczego z tego, co w różnych religiach jest prawdziwe i święte" (DRN 2) ${ }^{3}$ nie oznacza bynajmniej relatywizmu. Dialog międzyreligijny nie jest bowiem negocjowaniem. Jego celem nie jest wypracowanie wspólnego stanowiska i utworzenie nowej, wszechogarniającej struktury, która przez irenizm prowadziłaby do eklektyzmu lub synkretyzmu ${ }^{4}$, lecz nawiązanie relacji w duchu pokoju i zrozumienia. Przenoszenie negocjacyjnego znaczenia słowa «dialog» na dialog międzyreligijny powoduje krytykę, a nawet potępienie kontaktów międzyreligijnych ${ }^{5}$.

\subsection{Dialog międzyreligijny w ujęciu Kościoła katolickiego}

Jako podstawę dla wyprowadzenia kategorii «dialog międzyreligijny» przytaczam znaczenie pojęcia «dialog», ukazane w Encyklopedii katolickiej. Czytamy tam, że dialog jest to „rozmowa, mająca na celu wzajemne konfrontacje i zrozumienie poglądów, a także współdziałanie w zakresie wspólnego poszukiwania prawdy, obrony wartości ogólnoludzkich, i współpracy

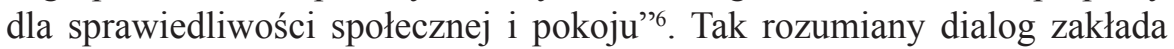
uznanie godności oraz wolności każdego człowieka i jego prawa do wyraża-

2 Por. Słownik wspótczesnego języka polskiego, t. 1, Warszawa 1998, s. 171.

3 Sobór Watykański II, Deklaracja o stosunku Kościoła do religii niechrześcijańskich Nostra aetate (odtąd DRN z odnośnym numerem), w: Sobór Watykański II, Konstytucje, Dekrety, Deklaracje, Poznań 2002, s. 334.

${ }^{4}$ Por. T. Pikus, Dialog międzyreligijny w katechezie szkolnej, „Wiadomości Archidiecezjalne Warszawskie" 12 (2004), s. 1297.

${ }_{5}^{5}$ Por. S. Grodź, Między poszukiwaniem porozumienia a błędnym kołem powrotu do konfliktów. Dialog międzyreligijny chrześcijan i muzutmanów, w: Teologia praktyczna, t. 4, Poznań 2003, s. 36.

${ }^{6}$ R. Łukaszyk, Dialog, w: R. Łukaszyk, L. Bieńkowski, F. Gryglewicz (red.), Encyklopedia Katolicka, t. 3, Lublin 1979, s. 1258. 
nia własnych poglądów (nawet obiektywnie błędnych) z racji światopoglądowego pluralizmu, wolności sumienia i religii oraz tolerancji.

Kościół włącza do humanistycznego wymiaru dialogu wymiar teologiczny $^{7}$. Dialog jawi się jako imperatyw chrześcijańskiego sumienia, które jest oświecone wiarą i kierowane miłością (por. UUS 8$)^{8}$. Teologiczną podstawą tak rozumianego dialogu jest wspólny dla całej ludzkości jeden cel, czyli Bóg, którego działanie przejawia się w Jego dobroci wobec każdego człowieka i ofiarowaniu mu zbawienia ${ }^{9}$. Kluczowym dokumentem Kościoła katolickiego, dotyczącym dialogu międzyreligijnego, jest soborowa Deklaracja o stosunku Kościoła do religii niechrześcijańskich Nostra aetate (DRN $1-5)^{10}$. Deklaracja ta ukazuje absolutną nowość w katolickim spojrzeniu na inne religie - dowodzi, że Kościół katolicki na wyznawców innych religii patrzy z szacunkiem, w myśl chrześcijańskiej zasady obdarzania wszystkich ludzi braterskimi uczuciami i miłością (por. DRN 1-5).

Istotę dialogu międzyreligijnego w ujęciu Kościoła katolickiego ukazują dokumenty wypracowane przez specjalnie do tego powołane instytucje Papieską Radę ds. Dialogu Międzyreligijnego (PRDM) oraz Kongregację Ewangelizacji Ludów. W opracowaniu zatytułowanym Dialog i przepowiadanie autorstwa tychże instytucji czytamy:

W kontekście pluralizmu religijnego termin «dialog» znaczy całokształt pozytywnych i konstruktywnych stosunków międzynarodowych z osobami i wspólnotami innych religii mających na celu wzajemne poznanie i obopólne wzbogacenie [...], pozostając jednak wiernym prawdzie i respektując wolność każdego. Implikuje on też świadectwo i pogłębienie swych przekonań religijnych ${ }^{11}$.

${ }^{7}$ „Pojęcie dialogu stało się jednym z kluczowych pojęć naszej kultury w ciagu XX wieku. Od czasu Soboru Watykańskiego II Kościół używa go chętnie w swych dokumentach, widząc jego głęboki sens teologiczny”. Konferencja Episkopatu Polski, Dialog - zadanie na nowy wiek. 28 XI 2003 r., „Biuletyn Ekumeniczny” 1 (2004) 129, s. 96.

${ }^{8}$ Por. Jan Paweł II, Encyklika Ut unum sint, w: Encykliki Ojca Świętego Jana Pawła II, Kraków 1996, s. 990-1074.

${ }^{9}$ Por. R. Łukaszyk, R. Miś, H. Zimoń, Dialog z religiami pozachrześcijańskimi, w: R. Łukaszyk, L. Bieńkowski, F. Gryglewicz (red.), dz. cyt., t. 3, s. 1278.

${ }^{10}$ Oprócz Nostra aetate, do głównych dokumentów soborowych, które zawierają przesłanie o dialogu międzyreligijnym, zalicza się: Lumen gentium, Gaudium et spes, Ad gentes oraz Dignitatis humanae. Wszystkie one były inspirowane tzw. «encykliką dialogu» Ecclesiam suam, ogłoszoną przez Pawła VI podczas trwania soboru. Por. A. Wąs, Sobór Watykański II a islam, http://religie.wiara.pl/doc/471757.Sobor-Watykanski-II-a-islam. (20 X 2010).

${ }^{11}$ Papieska Rada ds. Dialogu Międzyreligijnego, Kongregacja ds. Ewangelizacji Narodów, Dialog i przepowiadanie, Rzym 1991, nr 9. 
Tak też ujmuje znaczenie dialogu międzyreligijnego papież Jan Paweł II (1920-2006). Podkreślając, że Kościół ma prowadzić dialog ze wszystkimi środowiskami, wspólnotami i ludźmi ${ }^{12}$ zaznacza, że „szczere dążenie do dialogu wymaga z jednej strony wzajemnej akceptacji odmienności, a niekiedy wręcz sprzeczności, z drugiej zaś - poszanowania wolności decyzji, które ludzie podejmują $\mathrm{w}$ zgodzie $\mathrm{z}$ własnym sumieniem. Jest zatem konieczne, aby każdy człowiek, niezależnie od tego, jaką religię wyznaje, był świadomy nienaruszalnych wymogów wolności religijnej i wolności sumienia"13. Papież wyraża przekonanie, że jeśli mimo odmienności istnieje wspólna wola dialogu, można znaleźć obszary twórczej wymiany i rozwijać więzi owocnej przyjaźni, która z kolei może prowadzić do skutecznej współpracy w realizowaniu wspólnych celów i służyć wspólnemu dobru ${ }^{14}$.

Papież Benedykt XVI podejmuje zagadnienie dialogu międzykulturowego między innymi w encyklice Caritas in veritate, gdzie przestrzega przed eklektyzmem i zrównaniem kulturowym, które oddzielają kulturę od natury ludzkiej. Sprawia to, że kultury nie potrafią już odnaleźć swojej miary w naturze, która je przekracza, i ostatecznie sprowadzają człowieka jedynie do faktu kulturowego (por. CV 26). W orędziu na 44. Światowy Dzień Pokoju (1 stycznia 2011) Benedykt XVI zwraca uwagę na to, by w wychowaniu religijnym uczyć młode pokolenie uznawania w drugim człowieku brata i siostry, z którymi należy razem być w drodze i współpracować, ażeby wszyscy czuli się żywymi członkami jednej rodziny ludzkiej, z której nikt nie powinien być wykluczony ${ }^{15}$. W przekonaniu Papieża w zglobalizowanym świecie to właśnie „wielkie religie mogą być ważnym czynnikiem jedności i pokoju w rodzinie ludzkiej" 16 .

Katolicka perspektywa dialogu międzyreligijnego przywołuje normę etyczną znaną we wszystkich wielkich religiach, a powszechnie określaną jako «złota zasada».

12 Jan Paweł II, Orędzie na Światowy Dzień Pokoju. 1 stycznia 2001 roku. Dialog między kulturami droga do cywilizacji miłości i pokoju. 8 XII 2000, „L'Osservatore Romano” 10 (2001), s. 12.

${ }_{13}$ Jan Paweł II, Migracje, s. 4; por. Sobór Watykański II, Deklaracja o wolności religijnej Dignitatis humanae (DWR 2), w: Sobór Watykański II. Konstytucje, Dekrety, Deklaracje, Poznań 2002.

${ }^{14}$ Por. Jan Paweł II, Migracje, s. 3.

15 Benedykt XVI, Wolność religijna droga do pokoju. Orędzie na 44. Dzień Pokoju, http://diecezja.lublin.pl/news,169. (30.12.2010).

16 Tamże. 


\section{2. «Zlota zasada» jako podstawowa norma etyczna w dialogu międzyreligijnym}

„Wszystko, co byście chcieli, żeby wam ludzie czynili, i wy im czyńcie” (por. Mt 7, 12; Łk 6, 31). Rodowód tej chrześcijańskiej normy moralnej sięga siedemnastu wieków przed Chrystusem. Starożytni formułowali ją na dwa sposoby, negatywnie: „Nie czyń drugiemu, co tobie niemiłe!” i pozytywnie: „Czyń innym tak, jakbyś chciał, aby tobie czyniono!”. Pierwsza wersja odnosi się do unikania zła, druga zachęca do działania, do podjęcia inicjatywy i dostrzegania potrzeb drugiego człowieka ${ }^{17}$.

Wersja chrześcijańska jest pozytywna i nakłania do podejmowania działań wobec potrzebujących: czyń innym to, co chcesz, aby tobie czyniono ${ }^{18}$. Na powiązanie chrześcijańskiej miłości wzajemnej ze «złotą zasadą» wskazał papież Benedykt XVI w swoim orędziu telewizyjnym do mieszkańców Stanów Zjednoczonych Ameryki w 2008 roku. Powiedział wówczas: „Złotą zasadę dyktuje nam Pismo Święte, ale dotyczy ona przecież wszystkich ludzi, również niewierzących. Ta reguła jest zapisana w ludzkich sercach i wszyscy możemy się z nią zgodzić"19.

Niedługo po Jezusie «złotą zasadę», również w pozytywnej formie, ujął Seneka Młodszy (4? p.n.e.-65n.e.). W Listach moralnych do Lucyliusza pisał: „Żyj z niższym tak, jak chciałbyś, aby wyższy żył z tobą"20.

Tego rodzaju «złota zasada» istnieje $\mathrm{w}$ trzynastu wielkich religiach świata i tradycjach religijnych ${ }^{21}$. W judaizmie i w wielkiej tradycji rabinackiej miłość bliźniego jest „głównym prawem Tory” (Rabbi Akiba), bo skoro Bóg stworzył człowieka na swój obraz, wówczas kiedy czyni się coś dla jakiejkolwiek osoby, to jakby czyniło się to dla samego Boga. U Żydów spotykamy powiedzenie: „Co nienawistne tobie, nie czyń tego swemu bliźniemu" (Hiller, Talmud, Shabbad 31a). W tradycji islamu «złota zasada» brzmi następująco: „Nikt z was nie jest prawdziwie wierzącym, jeśli nie pragnie dla brata tego samego, czego pragnie dla siebie" (Hadith 13, Al-Bukhari) ${ }^{22}$.

17 Por. M. Rosik, Zlota zasada, „Niedziela” 44 (2006), s. 22.

18 Zob. też Katechizm Kościoła katolickiego, Poznań 2002, nr 1970, s. 465.

${ }_{19}$ Benedykt XVI, Złota zasada miłości jest zapisana w każdym sercu. Telewizyjne przestanie do mieszkańców Stanów Zjednoczonych Ameryki. 8 kwietnia 2008. Watykan, „L'Osservatore Romano" 5 (2008), s. 20.

${ }^{20}$ L. A. Seneka, Listy moralne do Lucyliusza, Edycja komputerowa, www.źródła.historyczne.prv.pl (20.12.2010).

${ }^{21}$ Por. Redakcja, Złota zasada postępowania, „My a Trzeci Świat” 7 (2002), s. 15.

${ }^{22}$ Ch. Lubich stwierdza, że tym, co łączy Ruch Focolari z muzułmanami, jest „duchowość Ruchu, w której oni znajdują bodziec i potwierdzenie, by bardziej zgłębić i całym 
W hinduizmie «złota zasada» zawiera się w słowach: „Taka jest istota powinności: 'Nie czyń drugiemu tego, co byłoby przyczyną cierpienia dla ciebie' (Mahabharata 5, 1517)”. Mahatma Gandhi (1869-1948) mówił: „Ty i ja jesteśmy jedno: raniąc ciebie, ranię również siebie samego" ${ }^{23}$. W buddyzmie zasadę tę wyraża zdanie: „Nie traktuj innych w sposób, jaki wobec ciebie uznałabyś za bolesny" (Udana - warga 5,18). W konfucjanizmie w «złotej zasadzie» podkreśla się miłowanie siebie i wielkoduszność wobec innych. Konfucjusz pisał: „w relacji z innymi daj z siebie wszystko i traktuj ich tak, jak sam chciałabyś być potraktowany, a odkryjesz, że jest to najkrótsza droga do wielkoduszności" (Mencius, VII.A.4) ${ }^{24}$.

«Złota zasada», którą Kościół katolicki ujmuje w przykazaniu miłości bliźniego, stanowi podstawę $\mathrm{w}$ dialogu międzyreligijnym prowadzonym przez Ruch Focolari.

\section{Ruch Focolari w dialogu międzyreligijnym}

Wydarzeniem, które zapoczątkowało nawiązanie stałych relacji Ruchu Focolari z wielkimi religiami, była uroczystość przyznania jego założycielce, Chiarze Lubich ${ }^{25}$, Nagrody Templetona za postęp w dziedzinie religii w Londynie, w $1977 \mathrm{roku}^{26}$. Obecni tam liczni przywódcy i przedstawiciele wielkich religii świata i tradycji religijnych: żydzi, muzułmanie, hinduiści, buddyści i sikhowie wyrazili chęć nawiązania kontaktu z Ruchem. Czym jednak jest Ruch Focolari? Jaki jest jego związek z wielkimi religiami?

sercem żyć duchowością islamu, a niektórzy również, by żyć jego mistyką". Ch. Lubich, Z wyznawcami wielkich religii, w: tenże, Charyzmat jedności, Kraków 2007, s. 466.

${ }^{23}$ W. Muhs, Parole del cuore, Milano 1996, s. 82.

${ }^{24}$ Cyt. za B. De Mori, La reciprocità 'per il bene' come luogo d'incontro tra i diritti e la Regola d'oro, w: C. Vigna, S. Zandaro (red.), La regola d'oro come etica universale, Milano 2005, s. 584.

${ }^{25}$ Właściwie Sylwia Lubich. Imię Chiara przyjęła, jako tercjarka III Zakonu św. Franciszka, poruszona świętością Klary z Asyżu. Por. F. Zambonini, Przygoda jedności, Kraków 1995, s. 34.

${ }^{26}$ Nagroda Templetona przyznawana jest przez Fundację Johna Templetona za postęp w dziedzinie religii oraz za dorobek służący dialogowi chrześcijaństwa ze współczesną myślą przyrodniczą. Laureatami tej nagrody byli m.in.: Matka Teresa z Kalkuty (1973); Brat Roger Schütz (1974); kardynał Suenens z Belgii (1976); Aleksander Sołżenicyn (1983); ks. Michał Heller (2008). 


\subsection{Ruch Focolari - główne założenia i cele}

Ruch Focolari jest jednym spośród wielu ruchów duchowej i społecznej odnowy, jakie powstały w Kościele katolickim w XX wieku ${ }^{27}$. Powstał w roku 1943 w Trydencie (Włochy) z inicjatywy Chiary Lubich. Nazwę focolare (wł. „ognisko domowe”) mieszkańcy Trydentu nadali rodzącej się wspólnocie, która świadczyła o braterskiej miłości oraz otwarciu na innych $^{28}$. W ciagu prawie 70 lat swego istnienia Ruch rozprzestrzenił się w 180 krajach, obejmując swym zasięgiem ponad 2 miliony osób z różnych narodów, kultur i religii. Są to osoby świeckie i w stanie duchownym, w różnym wieku i z różnych warstw społecznych. Celem specyficznym Ruchu jest przyczynianie się do zjednoczenia rodziny ludzkiej, pojęte jako dążenie do powszechnego braterstwa, co znajduje swoje źródło w słowach modlitwy Jezusa: „Aby wszyscy stanowili jedno” (J 17, 21), odczytywanej przez Ruch jako Jego testament. Cel ten jest realizowany na drodze pięciu dialogów: w obrębie Kościoła katolickiego; z chrześcijanami różnych Kościołów i wspólnot kościelnych; z wyznawcami różnych religii; z osobami o przekonaniach niereligijnych oraz w dialogu ze współczesną kulturą ${ }^{29}$. Środkiem do tego jest duchowość jedności, która podkreśla wspólnotowy wymiar życia chrześcijańskiego $^{30}$. W Ruchu Focolari, który formacją obejmuje wszystkie płaszczyzny życia człowieka, w zakres pojęcia «duchowość» wchodzi styl życia zgodny z zasadami Ewangelii. Styl ten, opierając się na wartościach chrześcijańskich, pozostaje otwarty na podobne idee obecne w innych reli-

${ }^{27}$ Por. J. Ratzinger, Ruchy kościelne i ich teologiczne miejsce, „Communio” 114 (1999), s. 78-101; P. Libera, Rola ruchów kościelnych w Europie na podstawie Adhortacji Jana Pawta II Ecclesia in Europa, „Nowe Miasto” 2 (2004), s. 8-13.

${ }_{28}$ Por. E. M. Fondi, M. Zanzucchi, Un popolo nato dal Vangelo, Milano 2003, s. 63.

${ }_{29}$ Por. Ch. Lubich, Statuti Generali. Opera di Maria (Movimento dei Focolari), Roma 2007, art. 6 .

${ }^{30}$ Por. tenże, Duchowość jedności nowa droga, Kraków 2004, s. 11-28. Na podstawie doświadczenia życia tą duchowością wypracowano w Ruchu doktrynę, która stopniowo przenika i ubogaca współczesną naukę i kulturę. Świadczą o tym m.in. liczne nagrody i tytuły doktora honoris causa, przyznane $\mathrm{Ch}$. Lubich przez różne instytucje międzynarodowe i uniwersytety na całym świecie. M.in.: Nagroda UNESCO za Wychowanie dla pokoju (Paryż 1997), Nagroda Praw Człowieka Rady Europy (Strasburg 1999), Nagroda „Pokoju Augsburskiego" (1988); oraz 16 doktoratów honoris causa, m.in.: z nauk społecznych (Polska, KUL 1996); teologii (Filipiny 1997, Tajwan 1997, Słowacja 2004, Wielka Brytania 2008), filozofii (Meksyk 1997), środków społecznego przekazu (Tajlandia 1997); psychologii (Malta 1998), pedagogiki (Waszyngton 2000), ekonomii (Brazylia 1998, Włochy 1999). (Por. http://www. focolare.org/page.php? codcat $2=1392 \&$ codcat $1=428 \&$ lingua $=I T \&$ titolo $=$ Chiara $\% 20 \mathrm{Lubi}$ ch\&tipo=riconoscimenti. 30.12.2010). 
giach i kulturach ${ }^{31}$. To sprawia, że wśród członków Ruchu są chrześcijanie z ponad 350 Kościołów (ok. 47 tys.), wyznawcy wielkich religii (żydzi, muzułmanie, hinduiści, buddyści - ponad 30 tys.) oraz osoby o przekonaniach niereligijnych (ok. 10 tys.), którzy w duchowości Ruchu odnajdują wartości, w które wierzą ${ }^{32}$. Co leży u podstaw tak owocnego dialogu?

\subsection{Pedagogia jedności źródłem i podstawą dialogu międzyreligijnego}

Dialog międzyreligijny w Ruchu Focolari nie jest celem samym w sobie, lecz ma prowadzić do wspólnego poszukiwania prawdy, która być może została już objawiona, lecz jeszcze nie została w pełni przyjęta. Jest to więc działanie i odpowiedzialne zaangażowanie na rzecz dobra wspólnego, które wymaga szczególnej postawy. W pedagogii jedności ${ }^{33}$ Ruchu, w zakresie wychowania do dialogu międzyrelijnego podkreśla się, że aby człowiek mógł się otworzyć na całą ludzkość, najpierw musi umieć otworzyć się na konkretną osobę, niezależnie od istniejących między nimi różnic. W akcentowaniu niezbywalnej wartości każdego człowieka, jego suwerenności, indywidualności i niepowtarzalności Ruch odwołuje się do zasad wypracowanych w nurcie myślowym, określanym ogólnie jako personalizm chrześcijański ${ }^{34}$. Podstawą relacji międzyosobowych jest chrześcijańska zasada miłości bliźniego, wychodzi się bowiem z założenia, że miłość do osobowego Boga konkretyzuje się w miłości do bliźniego, który jest drogą do Niego. Ch. Lubich stwierdza: „ten, kto jest obok mnie, został stworzony jako dar dla mnie, a ja zostałam stworzona jako dar dla tego, kto jest obok mnie. Na ziemi wszystko ze wszystkim jest w relacji miłości: każda rzecz z każdą

${ }^{31}$ Por. Ch. Lubich, Nowy styl życia chrześcijańskiego, w: tenże, Charyzmat, s. 45-49; tenże, Charyzmat jedności - charyzmat Europy. Przemówienie Chiary Lubich podczas Piatego Zjazdu Gnieźnieńskiego «Europa Ducha», „Nowe Miasto” 3 (2004), s. 11-19.

32 Por. tenże, Possono le religioni essere partner sul cammino della pace? Seminario interreligioso, Caux, 29 luglio 2003, „Nuova Umanità”152 (2004/2), s. 161-174.

${ }^{33}$ Sformułowanie «pedagogia jedności» zostało użyte po raz pierwszy przez Ch. Lubich w 2000 roku dla określenia teorii wychowania Ruchu Focolari. Por. Ch. Lubich, Lezione per la laurea honoris causa in pedagogia, Washington, 10 novembre 2000, „Nuova Umanità” $135 / 136$ (2001), s. 341-352.

${ }^{34}$ Odnosimy się do tej grupy teoretycznych inspiracji, która wychodząc z początków personalizmu E. Mouniera (1905-1950) i J. Maritaina (1882-1973), w definiowaniu podstawowych kategorii, w tym osoby oraz wspólnoty, w bezpośredni sposób nawiązuje do chrześcijaństwa, odwołując się do nauczania pierwszych soborów i roli prawdy o Bogu w Trójcy Osób Boskich, jak również nauczania wielkich Doktorów Kościoła, m.in. św. Augustyna (354-430), czy teologiczno-filozoficznej doktryny św. Tomasza z Akwinu (1225-1274). 
rzeczą. Trzeba jednak być Miłością, aby odnaleźć złotą nić łączącą byty" 35 . W jej przekonaniu jedynie miłość szanuje odmienność i pozwala widzieć drugiego takim, jakim jest w rzeczywistości, respektować go w jego istocie, uznać jego prawo do bycia sobą, pragnąć, by coraz bardziej stawał się sobą. Przyjąć więc drugiego w jego inności oznacza przyjmować z miłością drugie «ja», odmienność podmiotową, która może pogłębić sens istnienia ${ }^{36}$. Zwracając się do członków Ruchu, uzasadnia to w ten sposób:

Jeśli nie mamy miłości, nie mamy światła Bożego i wówczas dialog, jakikolwiek dialog, staje się płonny, bezowocny, jest tylko konwersacją, pogawędka, gadaniem. Tymczasem dialog powinien być kochaniem, powinniśmy być miłością, bo tylko Duch Święty w nas może nam naprawdę pomóc prowadzić dialog, udzielać właściwych odpowiedzi, być twórczymi, i odkryć ewentualne błędy $\mathrm{u}$ innych, nawet te skrzętnie ukryte pod płaszczykiem fascynujących teorii ${ }^{37}$.

Tak prowadzony dialog międzyreligijny chroni przed synkretyzmem, prowadzi do odkrywania korzeni własnej religii, tego, co ją łączy z innymi religiami, a w konsekwencji do doświadczenia braterstwa.

Metodologia prowadzenia dialogu, jaką proponuje Ruch, jest bardzo prosta, wyraża się w tak zwanej «sztuce miłowania», którą można streścić w czterech podstawowych normach: ,kochać wszystkich; kochać jako pierwszy, kochać jak siebie samego, jednoczyć się"38. Miłość, o jakiej mówi się $\mathrm{w}$ «sztuce miłowania», ma specyficzne wymagania, dlatego jest ona określana jako arte, czyli umiejętność, pewnego rodzaju sztuka ${ }^{39}$, a jej zasadniczymi wymaganiami są:

- powszechność, bo wymaga, aby kochać wszystkich, nawet nieprzyjaciół;

- konkretność, ponieważ wzywa do tego, by kochać przez czyny, a nie tylko uczuciowo lub przez słowa;

- wzajemność, ponieważ należy kochać w taki sposób, aby poruszyć u drugiego zdolność do kochania ${ }^{40}$.

${ }^{35}$ Ch. Lubich, Pensieri, w: tenże, Scritti spirituali, t.1, Rzym 1997, s. 143.

${ }^{36}$ Por. tenże, Charyzmat jedności i psychologia, w: tenże, Charyzmat, s. 322-326.

37 Tenże, Cosa è un dialogo?, w: N. Pozzi, V. Araujo (red.), Atti - il quinto dialogo, Rocca di Papa 2010, s. 7.

${ }^{38}$ Zob. tenże, L'arte di amare, Roma 2005.

${ }^{39}$ Por. G. J. Pastiaux, Précis de pédagogie, Paris 1997, s. 4.

${ }^{40} \mathrm{Ch}$. Lubich, Discorso di Chiara in occasione dell'onorificenza data dall'ambasciatore di Cina presso la Santa Sede, Castelgandolfo, 13 febbraio 2001, w: Le ragioni della convivenza. La convivenza delle ragioni. Atti del Convegno. Castelgandolfo, 1-3 giugno 2001, Roma 2001, s. 25. 
W «sztuce miłowania» Ruch wydobywa pewną dialektykę miłości, której uczy chrześcijaństwo, a która polega na czynieniu daru z siebie dla drugiego (por. KDK 24) ${ }^{41}$. Taka postawa na ogół przyzywa wzajemność, co jest niezbędnym warunkiem osiagnnięcia jedności.

W książce L'arte di amare (Sztuka miłowania), którą można by uznać za podręcznik na temat tej metody prowadzenia dialogu międzyreligijnego, Ch. Lubich wyjaśnia, że kochać wszystkich oznacza rozszerzyć serca i uwolnić się od uprzedzeń, bo wszyscy są kandydatami do jedności. Precyzuje, że nie jest to pojęcie abstrakcyjne, oznacza bowiem, że trzeba zacząć od bliźniego, to znaczy od tego, kto w danej chwili jest najbliżej. Należy kochać w sposób konkretny, to znaczy: umieć dla drugiego „stracić czas”, służyć mu, być dla niego jak matka ${ }^{42}$. Aby prowadzić dialog należy «kochać jako pierwszy». Oznacza to, że w relacji z drugim człowiekiem należy podejmować inicjatywę, gdyż ,jesteśmy stworzeni jako dar jeden dla drugiego, a realizuje się to poprzez okazywanie miłości drugiemu, zanim ten drugi nas nią obdarzy" "33. Zdaniem autorki, taka postawa prowadzi do przezwyciężania lęku, jaki powstaje u człowieka z powodu własnej słabości, a także ze względu na ograniczenia innych. Brak inicjatywy w relacji do drugiego człowieka najczęściej jest powodowany brakiem podstawowej wiedzy o nim, nieśmiałością lub uprzedzeniem, dlatego podkreśla się w Ruchu istotne znaczenie wzajemnego poznawania się ${ }^{44}$.

Kolejnym krokiem w prowadzeniu dialogu międzyreligijnego jest «kochać każdego jak siebie samego». Ten krok wyznacza miarę miłości, którą określa formuła, aby czynić drugim to, co chcielibyśmy, by nam czyniono, i nie czynić tego, czego nie chcielibyśmy, by nam czyniono. Ta norma postępowania, brzmiąca w chrześcijaństwie: „miłuj swego bliźniego, jak siebie samego!” (Mt 19, 19) jest treścią «złotej zasady». Ch. Lubich jest przekonana, że postrzeganie drugiego w pozytywny sposób uzdalnia do prawdziwego miłowania, co czyni człowieka wolnym ${ }^{45}$ i pozwala mu prowadzić dialog, tzn.: „ustawić się na tym samym poziomie, co rozmówca i nie uważać się za kogoś lepszego [...], szczerze słuchać swojego rozmówcę, lecz aby to uczynić, trzeba odsunąć własne myśli, odczucia i przywiązania, aby niejako

${ }^{41}$ Por. Sobór Watykański II, Konstytucja duszpasterska o kościele w świecie współczesnym Gaudium et Spes (KDK), w: Sobór Watykański II. Konstytucje, s. 550-551.

${ }^{42}$ Por. Ch. Lubich, L'arte di amare, s. 31-38.

${ }^{43}$ Tenże, La spiritualità per un vivere insieme, Alla VII Assemblea della Conferenza Mondiale delle Religioni per la Pace, Amman, 29 novembre 1999, „Nuova Umanità” 128 (2002/2), s. 152.

${ }^{44}$ Tenże, L'arte di amare, s. 49.

45 Tenże, Klucz do jedności, Katowice 1989, s. 54-55. 
«wejść w drugiego»" ${ }^{46}$. Pomaga w tym kolejny krok sztuki miłowania ujęty w formule «jednoczyć się», co oznacza - jak thumaczyła Lubich w swoim przemówieniu w siedzibie UNESCO w 1996 roku - „wzięcie na siebie ciężarów innych, uczynienie swoimi ich myśli, cierpień i radości" ${ }^{47}$. Podkreśla ona jednak, że «jednoczyć się» z drugim nie jest taktyką lub metodą oddziaływania zewnętrznego ani tylko postawą dobrej woli, otwartości i szacunku czy brakiem uprzedzeń. Jest to postawa, która „wymaga całkowitej «pustki»" ${ }^{48}$, ponieważ „nie można wniknąć w duszę brata, aby go pojać, zrozumieć i dzielić z nim jego cierpienie, jeśli nasza dusza jest zajęta jakimś zmartwieniem, osądem, myślą" ${ }^{4}$. Podstawowym zachowaniem jest tu autentyczna empatia. Włoski psycholog Mario Giostra uważa, że zasadnicza nowość, jaką do postawy klasycznej empatii wnosi Ch. Lubich, polega na tym, że wydobywa ona i dowartościowuje istotny etap w procesie przechodzenia od «ja» do «ty». Według założycielki Ruchu uczynienie «pustki» w sobie, które zakłada konieczność wyrzeczenia się siebie, tzn. odsunięcia własnego sposobu postrzegania danej rzeczywistości, uwolnienia się od wszelkich uprzedzeń, odcinania tego wszystkiego, co może utrudniać słuchanie drugiego i bycie dla niego w pełni, może się dokonać tylko na bazie autentycznej miłości do drugiego człowieka, a wzorem jest tu postawa Jezusa ${ }^{50}$. Doświadczenie Ruchu Focolari pokazuje, że postawa «jednoczenia się» uczy otwartości, która rodzi się z przekonania, że od każdego człowieka można się czegoś nauczyć, a jednocześnie z poczucia własnej tożsamości, która ochrania przed jakimikolwiek formami pomieszania i synkretyzmu. Ch. Lubich wyjaśnia, że «jednoczenie się» z drugą osobą sprawia, że otwiera się ona przed nami i podarowuje siebie, ubogacając nas ${ }^{51}$.

Opisane powyżej cztery kroki «sztuki miłowania» są stosowane w środowisku Ruchu Focolari i kręgach chrześcijaństwa, lecz zostały zaproponowane przez Chiarę Lubich jako styl życia także poza Ruchem, w obszarze innych religii i kultury laickiej ${ }^{52}$.

46 Tenże, Intervento alla radio Vaticana, „Mariapoli” 2 (2000), s. 14.

${ }^{47}$ Tenże, Premio educazione per la pace. UNESCO, Parigi 17.12.1996, Archivio Movimento dei Focolari (Italia).

48 Tenże, Przemówienie wygłoszone w katedrze w Aachen 13 listopada 1998, w: tenże, Charyzmat, s. 469.

${ }^{49}$ Tenże, Klucz do jedności, s. 357-358.

${ }^{50}$ Cyt. za M. Giostra, Comunicazione empatica e 'farsi uno': una via per strutturare nuovi modelli di intervento nel campo del disagio sociale, „Nuova Umanità” 162 (2005/6), s. 919-927.

${ }^{51}$ Por. Ch. Lubich, L'arte di amare, s. 85.

${ }^{52}$ Zob. tenże, All'UNESCO, nel conferimento del premio per l'educazione alla pace, „Nuova Umanità” 108 (1996/6), s. 639-644; tenże, La spiritualità, s. 150; tenże, Possono le religioni, s. 161-174. 


\section{Wymiar praktyczny dialogu międzyreligijnego w Ruchu Focolari}

Dialog międzyreligijny jest prowadzony w Ruchu Focolari na kilku płaszczyznach:

- «dialog życia» rodzi się z codziennych kontaktów z wyznawcami innych religii 53 ;

- «dialog działań» wyraża się we współpracy w różnych organizacjach międzynarodowych i międzyreligijnych ${ }^{54}$;

- «dialog ekspertów» prowadzony jest przez członków Ruchu, znawców różnych tradycji i religii 55 ;

- «dialog doświadczeń religijnych» polega na wymianie doświadczeń z życia, dokonywanych w świetle świętych Ksiąg i tradycji poszczególnych religii ${ }^{56}$.

W relacjach Ruchu o charakterze międzyreligijnym, podstawą jest budowanie wspólnoty w oparciu o afirmację wspólnych wartości, elementów wiary oraz komunikowanie i przekazywanie doświadczeń duchowych, a także płaszczyzn wzajemnej współpracy. Taka strategia dialogu jest spójna $\mathrm{z}$ nauczaniem soborowym wyrażonym w dokumencie Nostra aetate ${ }^{57}$. Ukazują to konkretne owoce kontaktów Ruchu z wyznawcami judaizmu, islamu, hinduizmu i buddyzmu.

${ }^{53}$ Por. P. Loriga, Graz. Ecumenismo di popolo, „Città Nuova” 14 (1997), s. 24-35.

${ }^{54} \mathrm{Na}$ przykład w ramach Światowej Konferencji Religii dla Pokoju, której Ch. Lubich była honorowym przewodniczącym.

${ }^{55}$ W tym celu Ruch organizuje sympozja i seminaria: buddyjsko-chrześcijańskie odbyły się 2004 r. (Rzym) i w 2006 r. (Osaka-Japonia); dialogu żydowsko-chrześcijańskiego i dialogu islamu z chrześcijaństwem w latach 2005 i 2007 (Castel Gandolfo). Widocznymi owocami tych sympozjów był udział ich uczestników: hinduistów, muzułmanów, buddystów oraz rabinów i żydowskich uczonych w audiencjach u papieży: Jana Pawła II i Benedykta XVI.

${ }_{56}$ Por. M. Zanzucchi, Già e non ancora. Il dialogo della vita, „Città Nuova” 9 (1997), s. $28-31$.

${ }^{57}$ S. Nagy we Wprowadzeniu do tego dokumentu zwraca uwagę na fakt, że „całkowicie nowym pierwiastkiem w przyjętym przez Sobór ustosunkowaniu się do religii niechrześcijańskich jest afirmacja religijnych wartości, kryjących się w formach religijnych niechrześcijańskich, od prymitywnych religii człowieka znajdującego się w początkowej fazie rozwoju cywilizacyjnego aż po wielkie, legitymujące się dużą dojrzałością religie hinduizmu, buddyzmu i islamu". S. Nagy, Wprowadzenie do Deklaracji o stosunku Kościoła do religii niechrześcijańskich, w: Sobór Watykański II. Konstytucje, Dekrety, Deklaracje, Poznań 1968, s. 332. 


\subsection{W dialogu z żydami}

Ruch Focolari prowadzi dialog oparty na miłości i współpracy z żydami, zwłaszcza na Bliskim Wschodzie, w Europie, w Ameryce Południowej oraz w USA ${ }^{58}$. W 1996 roku w Castel Gandolfo miało miejsce pierwsze międzynarodowe spotkanie żydów zaangażowanych w Ruchu. W 1997 roku Ch. Lubich otrzymała tytuł doktora honoris causa w dziedzinie nauk humanistycznych na Sacred Heart University Fairfield w Connectiucut (USA) za „zasługi w dziedzinie dialogu chrześcijańsko-żydowskiego"59. Rabin Jack Bemporad - ówczesny przewodniczący Centrum Porozumienia Chrześcijańsko-Żydowskiego działającego przy tym Uniwersytecie, jako promotor tego doktoratu - uzasadniając decyzję o jego przyznaniu, powiedział między innymi: „Chiara Lubich i jej współpracownicy starają się stworzyć światowe laboratorium, w którym doświadcza się tego, co my opracowujemy na płaszczyźnie teoretycznej. Opierają się oni na dwu filarach: idei miłości i idei jedności" 60 .

W 1998 roku Ch. Lubich była gościem żydowskiej organizacji B’nai B'rith International w Buenos Aires. Została tam zaproszona przez należących do Ruchu Focolari członków wspólnoty żydowskiej z Argentyny i Urugwaju. O tym spotkaniu tak pisała: „Spotkaliśmy się z wielkim wzruszeniem i zawarliśmy pakt miłości wzajemnej, tak głęboko przeżyty, że mieliśmy wrażenie, iż w jednej chwili przezwyciężyliśmy wieki prześladowań i braku zrozumienia" ${ }^{61}$. Potwierdzeniem tej rzeczywistości są słowa Eliasa Zviklica, gubernatora B'nai B'rith International, który powiedział o Chiarze Lubich: „Ta kobieta prowadzi nas do nowej otwartości, zapoczątkowanej przez Jana XXIII i kontynuowanej przez Jana Pawła II, angażując setki tysięcy osób, które zrozumiały, że nie istnieje inna możliwość dla rodzaju ludzkiego, jak ta, żeby być w pełni człowiekiem" 62 .

Przykładem kontynuowania nawiązanych wówczas kontaktów jest udział żydów w corocznym Dniu Pokoju, który jest obchodzony w „,mia-

58 Por. P. Coda, Prologo nella sinagoga di Roma, w: tenże, Le luci della menorah. Con Chiara Lubich in Argentina e Brasile, Roma 1998, s. 7.

59 Tenże, Nella moschea di Malcolm X.Con Chiara Lubich negli Stati Uniti e in Messico, Roma 1997, s. 33n.

${ }^{60}$ www.focolare.org - link: Le vie del dialogo - con l'ebraismo. (30.12.2010).

${ }^{61}$ Ch. Lubich, Przemówienie wygłoszone $w$ katedrze w Aachen, s. 467; por. P. Coda, Le luci, s. 128-139.

${ }^{62}$ R. Catalano, Tam, gdzie nie ma miłości, zanieś ja, ,Nowe Miasto” 2-3 (2008), s. 115-116 . 
steczku" ${ }^{63}$ Ruchu Focolari O’Higgins w Argentynie. Rabin Mario Hendler, przewodniczący Żydowskiego Zgromadzenia Latynoamerykańskiego - który systematycznie uczestniczy w tych celebracjach i docenia ich wartość wychowawczą - uważa, że „dopiero w przyszłości zrozumiemy wagę i znaczenie tych historycznych wydarzeń, w których obecnie bierzemy udział" ${ }^{64}$.

\section{2. $\mathrm{W}$ dialogu $\mathrm{z}$ muzułmanami}

Kontakty Ruchu z muzułmanami zostały zapoczątkowane pod koniec lat sześćdziesiątych ubiegłego wieku na Bliskim Wschodzie, w Europie, a także w Stanach Zjednoczonych. Lubich stwierdza: „Tym, co natychmiast pozwoliło nam się czuć szczególnie blisko z braćmi muzułmanami, jest podzielanie z nimi głębokiej wiary w Miłość Boga, co Koran wyraża w słowach: «On jest nam bliższy niż tętnica szyjna»" ${ }^{\prime 65}$.

W 1997 roku w Meczecie Malcolma Shabazza w Nowym Jorku (Harlem) miało miejsce spotkanie założycielki Ruchu Focolari z trzema tysiącami muzułmanów ${ }^{66}$. Po latach wspólnego doświadczenia braterstwa Chiara Lubich została tam zaproszona przez imama Wallace Deena Mohammeda (1933-2008) założyciela American Muslim Mission. Lubich, przemawiając do nich, zwróciła uwagę między innymi na to, że chrześcijan i muzułmanów łączy na przykład wiara w jedynego Boga, całkowite poddanie się woli Bożej, szacunek dla Jezusa i Maryi, a także praktykowanie prawdziwej i bezinteresownej miłości do każdego bliźniego, szczególnie tam, „gdzie przemoc i nietolerancja rasowa oraz religijna próbują wykopać przepaść między członkami społeczeństwa" ${ }^{67}$. Odwołując się do «złotej zasady», przytoczyła słowa z antycznej tradycji islamskiej, w której podkreśla się: „Nikt z was nie

${ }^{63}$ Są to małe społeczności, tworzone przez członków Ruchu osiedlonych na określonym terenie stanowiącym jego własność. Podstawowym celem «miasteczek» jest wspólnotowe realizowanie w codziennym życiu zasady miłości wzajemnej, a w konsekwencji dawanie świadectwa przez ukazywanie modelu społeczeństwa żyjącego tą zasadą. W roku 2010 na wszystkich kontynentach istniały 34 «miasteczka». Każde z nich ma swoją specyfikę, odpowiadająca potrzebom i rzeczywistości, w jakiej powstało. Każde też - w sposób sobie właściwy - ukazuje drogę dialogu i integracji z lokalną społecznością. Zob. R. Saltini, Laboratorium społeczności chrześcijańskiej, „Nowe Miasto” 3 (2006) s. 14-15.

${ }^{64}$ Por. E. M. Fondi, M. Zanzucchi, dz. cyt., s. 397.

${ }^{65}$ Ch. Lubich, Co nas łaczy. W Meczecie im. Malcolma Shabazza w Harlemie, „Nowe Miasto" 4 (1997), s. 20-21.

${ }^{66}$ Por. M. Zanzucchi, Wśród czarnych muzutmanów, „Nowe Miasto” 4 (1997).

${ }^{67}$ Ch. Lubich, Discorso nella moschea di Malcolm X, New York 1996. Archivio Movimento Focolari (Italia). 
jest wierzącym, dopóki nie będzie pragnął dla brata tego, czego pragnie dla siebie" ${ }^{\prime 68}$.

Z Ruchem Focolari ma kontakt około 7 tysięcy muzułmanów określających się jako „przyjaciele Ruchu”. Są to imamowie, praktykujący wierni oraz tacy muzułmanie, którzy przez spotkanie z Ruchem - jak twierdził imam W. D. Mohammed - powrócili do praktykowania ,pięciu filarów islamu” ${ }^{\prime 9}$. Nierzadko sami muzułmanie inicjowali spotkania dla podtrzymywania więzi z chrześcijanami. Komunikowanie sobie doświadczenia transcendentnego prowadziło konsekwentnie do powstawania małych wspólnot chrześcijan i muzułmanów realizujących zasady Ruchu. Takie doświadczenia stają się podstawą do wspólnego budowania rzeczywistości powszechnego braterstwa, do czego zachęca nauczanie soborowe. W dokumencie Nostra aetate po raz pierwszy oficjalnie w dziejach Kościoła nawołuje się katolików, aby z muzułmanami „w interesie całej ludzkości wspólnie strzegli i rozwijali sprawiedliwość społeczna, dobra moralne oraz pokój i wolność" (DRN 3). W Ruchu Focolari przykładem tego jest „miasteczko” Ruchu w Dalwal (Pakistan), w którym świadectwo o miłości wzajemnej dają mieszkający tam na stałe chrześcijanie i muzułmanie ${ }^{70}$.

\subsection{W dialogu $z$ hinduistami}

W roku 2001 w Combatoire (Indie) Ch. Lubich została laureatem „Nagrody Obrońcy Pokoju" przyznanej jej przez dwie gandystowskie organizacje: Shanti Ashram i Sarvodaya Movement ${ }^{71}$. W umotywowaniu tego wyróżnienia zostaje doceniony wkład Lubich, a poprzez nią całego Ruchu Focolari, w wychowywanie młodych pokoleń do pokoju i jedności rodziny ludzkiej ${ }^{72}$.

Do pogłębiania dialogu pomiędzy chrześcijanami z Ruchu Focolari a hinduistami przyczyniło się także spotkanie Chiary Lubich ze studenta-

${ }^{68}$ Tamże; por. F. Ciardi, Luce e la tua Parola. Dialogo interreligioso e annuncio del Vangelo, Roma 2005, s. 134-151.

${ }^{69}$ Por. Ch. Lubich, L'unità e Gesù crocifisso e abbandonato, fondamenti per una spiritualità di comunione, w: tenże, Il dialogo è vita, Roma 2007, s. 69. Pięć filarów islamu są to podstawowe obowiązki każdego muzułmanina: 1. Szahada - Wyznanie wiary; 2. Salat 5 razy dziennie modlitwa; 3. Saum - Post w miesiącu ramadan; 4. Zakat - Jałmużna dla biednych; 5. Hadżdż - Pielgrzymka do Mekki, choć raz w życiu. Por. MZW, Czym jest pięć filarów islamu, http://www.muzulmanie.pl/wyd_br.php?id_br=oi\&id_broi=cjp. (20.12.2010).

${ }^{70}$ Por. E. M. Fondi, M. Zanzucchi, dz. cyt, s. 392 i $448-450$.

${ }^{71}$ Por. Dalla Redazione, Dialogo con Indù. Si apre la via dell'India, „Mariapoli” 1 (2001), s. 4-29.

${ }^{72}$ Por. E. M. Fondi, M. Zanzucchi, dz. cyt., s. 405. 
mi na Uniwersytecie Somaiya w Bombaju. Jest to jedna z najważniejszych hinduskich uczelni zaangażowanych w dialog międzyreligijny na płaszczyźnie akademickiej. Owocem tego spotkania było nawiązanie kontaktu także z Centrum Kultury Bharatiya Sanskriti Peetham z tegoż uniwersytetu oraz z Bharatiya Vidya Bhavan i Swadhyaya Family - hinduskim ruchem obecnym w Indiach, liczącym ponad 8 milionów członków ${ }^{73}$.

\section{4. $\mathrm{W}$ dialogu $\mathrm{z}$ buddystami}

Ruch Focolari rozpoczął kontakty z buddyzmem w roku 1979, gdy Ch. Lubich spotkała się z Nikko Niwano (1906-1999) ${ }^{74}$, założycielem wielotysięcznego świeckiego ruchu odnowy buddyjskiej Rissho Kosei-kai, a także współzałożycielem Światowej Konferencji Religii dla Pokoju (World Conference of Religions for Peace). W 1981 roku - na jego zaproszenie Lubich przedstawiła swoje doświadczenie chrześcijanki dziesięciu tysiącom animatorów tegoż Ruchu, zgromadzonym w buddyjskiej świątyni w Tokio ${ }^{75}$. Ch. Lubich zaznacza jednak, że drogę do tego wydarzenia utorowało świadectwo życia miłością wzajemną małych wspólnot Ruchu Focolari w Japonii. Spotkanie buddystów z Ch. Lubich w Tokio zapoczątkowało współpracę na polu obrony praw człowieka i promowania pokoju ${ }^{76}$.

Ruch nawiązał kontakty także z buddyjską Szkołą Tendai-shu oraz z tajlandzkim odłamem buddyzmu Theravada. Doświadczenie braterstwa we wspólnocie, jakie stało się udziałem kilku mnichów tajlandzkich w międzynarodowym „miasteczku” Ruchu w Loppiano (Włochy), przyczyniło się do zaproszenia Chiary Lubich do Tajlandii ${ }^{77}$. W 1997 roku, na prośbę Wielkiego Mistrza Ajahna Thonga, Lubich mówiła o dialogu międzyreligijnym i swoim duchowym doświadczeniu do ponad 800 studentów (osób świeckich, mnichów i mniszek), zgromadzonych na uniwersytecie buddyjskim Mahachula-

${ }^{73}$ Por. Dalla Redazione, Simposio fra indù e cristiani, „Mariapoli” 6 (2002), s. 10-11.

${ }^{74}$ Nikko Niwano, buddysta, w 1965 roku spotkał się z papieżem Pawłem VI; na jego zaproszenie uczestniczył w obradach Soboru Watykańskiego II jako jedyny obserwator niechrześcijanin. Por. Ch. Lubich, Incontri con Oriente, Roma 1986, s. 15.

${ }^{75}$ Por. tenże, L'esperienza spirituale. Testo del discorso pronunciato da Chiara Lubich nella Grande Aula Sacra di Tokio, il 28 dicembre 1981, w: Ch. Lubich, Incontri con Oriente, s. $18-25$.

${ }^{76}$ Młodzi dla Jedności z Ruchu Focolari uczestniczyli w spotkaniach organizowanych przez japońskie stowarzyszenie buddyjskie Myochikai w 1997 i w 2000. Por. http://www. focolare.org/page.php?codcat $2=508 \&$ codcat $1=105 \&$ lingua $=I T \&$ titolo $=$ nuove $\% 20$ generazioni\&tipo=iniziative\%20internazionali. (10.12.2010).

77 Por. P. Coda, Viaggio in Asia, Roma 1997, s. 32-36; Ch. Lubich, Przemówienie wygloszone w katedrze w Aachen, s. 465-466. 
longkorn w Chiang Mai (Tajlandia) ${ }^{78}$. W wystąpieniu tym podkreśliła, że dla chrześcijan miłość do każdego człowieka stanowi zasadę wszystkich relacji międzyludzkich, a jednocześnie jest drogą w dążeniu do doskonałości: „Dla nas chrześcijan ważne jest to, co jest napisane w naszych świętych Pismach: «bądźcie doskonali, tak jak doskonały jest Ojciec wasz w Niebie». Lecz doskonałość można osiagnąć tylko poprzez miłość. Przeczytałam, że wasz Budda każdego ranka, gdy się obudził, zadawał sobie pytanie: komu dzisiaj mogę uczynić coś dobrego? I to jest wszędzie najważniejsze"79. Owocem tej wizyty było otwarcie w Chiang Mai - na prośbę samych buddystów dwóch wspólnot Ruchu Focolari dla podtrzymywania kontaktów ze światem buddyjskim.

Dotychczasowe doświadczenie dialogu buddyjsko-chrześcijańskiego w Ruchu Focolari - tak z osobistościami świata akademickiego, jak i ze zwykłymi wyznawcami - potwierdza się w opinii wyrażonej przez antropologa i teologa Aldo N. Terrina, że ,poznanie buddyzmu od wewnątrz wymaga głębokiego doświadczenia religijnego, wymaga "spojrzenia mistycznego», aby rozpoznać prawdę, której jest nosicielem" $"$.

Ruch Focolari współdziała na rzecz pokoju i jedności w świecie z takimi ruchami, jak: Rissho Kosei-kai (Japonia, buddyzm, 6 mln członków); Society of Muslims (USA, islam, 2 mln członków); Swadhyaya Family (Indie, hinduizm, $8 \mathrm{mln}$ członków). Ponadto około trzydziestu tysięcy wyznawców różnych religii, podzielając - na ile to możliwe - idee Ruchu Focolari, współpracuje z nim w realizowaniu jego celów ${ }^{81}$.

\section{Formacja do dialogu międzyreligijnego w Ruchu Focolari}

Dla koordynowania działań w zakresie dialogu międzyreligijnego zgodnie z nauczaniem Kościoła katolickiego Ruch Focolari powołał do istnienia Centrum Dialogu Międzyreligijnego z siedzibą w Rocca di Papa (Włochy) ${ }^{82}$. $\mathrm{W}$ trosce o rzetelną duchową i intelektualną formację członków Ruchu na tej płaszczyźnie w kilku ,miasteczkach” Ruchu powstały specjalistyczne szkoły dialogu międzyreligijnego, w których zajęcia prowadzą specjaliści odpo-

${ }^{78} \mathrm{Ch}$. Lubich była pierwszą kobietą i chrześcijanką przemawiającą na tym uniwersytecie. Por. D. Cumer, Come dialogare? I dialoghi nell'Opera di Maria, „Gen's” 3-4 (1998), s. $15-16$.

${ }^{79}$ Ch. Lubich, Viaggio a Ciang Mai, w: P. Coda, Viaggio in Asia, s. 50-51.

${ }^{80}$ A. Terrin, Spiegare o comprendere la religione? Le scienze della religione a confronto, Bologna 1983, s. 218.

81 Por. Ch. Lubich, L'unità e Gesù, s. 70.

${ }^{82}$ Zob. info.dialogointerreligioso@focolare.org. 
wiednio do tego przygotowani. Takie szkoły istnieją na Filipinach - Szkoła Dialogu z Religiami Wschodu oraz w USA - Szkoła Dialogu Międzyreligijnego z Islamem i Judaizmem. Natomiast w „miasteczku” Piero w Kenii istnieje Szkoła Inkulturacji.

W Ruchu Focolari wychowaniem do dialogu z wyznawcami innych religii są objęci wszyscy członkowie, także młodzież i dzieci. Służy temu młodzieżowa prasa Ruchu oraz międzynarodowe spotkania i kongresy. Ch. Lubich wykorzystywała różne okazje, aby przekazywać młodym pokoleniom to doświadczenie. Zwracając się do adolescentów Ruchu z różnych religii podczas ich międzynarodowego spotkania - Superkongres - które odbyło się w 2002 roku w Rzymie, powiedziała:

Jeśli ty, młody muzułmaninie, będziesz kochać, jeśli ty, chrześcijaninie, będziesz kochać i ty - młody żydzie i hinduisto będziecie kochać, to szybko dojdziecie do miłości wzajemnej. I w taki sposób zrealizuje się fragment powszechnego braterstwa. Jeśli tak będziemy czynić, wy młodzi i my dorośli, to powszechne braterstwo będzie się rozszerzać, rozkwitnie solidarność, dobra materialne będą rozdzielane sprawiedliwie, a nad światem zajaśnieje tęcza pokoju: nad tym światem, który za kilka lat będzie w waszych rękach ${ }^{83}$.

\section{Zakończenie}

W Ruchu Focolari prowadzić dialog (dialogować) nie jest jakimś optional. Jest to współistotne $\mathrm{z}$ jego tożsamością. Fokolarini nie narodzili się z jakiegoś projektu opracowanego przy biurku, lecz dzięki charyzmatycznej inspiracji, którą Duch Święty obdarzył Chiarę Lubich. Świadczy o tym fakt, że gdy w pierwszych czasach Ruchu zapytano ją, czy pragnie założyć stowarzyszenie na rzecz dialogu ekumenicznego, odpowiedziała zdecydowanie negatywnie, wydawało jej się bowiem wówczas, że cele Ruchu ograniczają się do ram Kościoła katolickiego. I to samo dotyczyło relacji Ruchu z wyznawcami innych religii. Jednak liczne wydarzenia, jakie zaistniały w jej życiu oraz w życiu towarzyszących jej osób, wskazywały wyraźnie na konieczność przygarniania każdego, a przyjęcie (ogarnięcie) jest pierwszym stopniem w dialogu.

Rozszerzanie się Ruchu w świecie ukazuje, że rozprzestrzenianie się idei jedności nie wiązało się wprost z działaniami misyjnymi, lecz raczej

${ }^{83}$ Ch, Lubich, Discorso al Supercongresso 2002 a Roma, il 26 maggio 2002, w: E. M. Fondi, M. Zanzucchi, dz. cyt., s. 260; por. Ch. Lubich, Londra 1977: è iniziato il dialogo dell'amore, w: tenże, Colloqui con i gen. Anni 1975/2000, Rzym 2001, s. 41-42. 
z życiem miłością według proponowanej przez Chiarę Lubich «sztuki miłowania». «Jednoczenie się» - ta nowa kategoria, która jest modyfikacją słów św. Pawła (,stałem się wszystkim dla wszystkich”, 1 Kor 9, 22), w Ruchu Focolari wyznacza właściwą „metodę” prowadzenia dialogu międzyreligijnego: «jednoczyć się», żyjąc «złotą zasadą».

\section{Dialogo intereligioso nella vita e nell'agire del Movimento dei Focolari (Riassunto)}

Questo contributo mette in evidenza la dimensione pratica del dialogo interreligioso promosso dal Movimento dei Focolari, fondato nel 1943 in Italia da Chiara Lubich (1920-2008) e presente in oltre 160 paesi. Il suo scopo specifico è l'unità della famiglia umana (cf. Gv 17, 21) e perciò il dialogo interreligioso è coesistente alla sua identità. Esso è il frutto della realizzazione nella vita, specie nelle società multiculturali e multireligiose, del principio cristiano dell'amore del prossimo (cf. Mt 7,12). Come norma etica fondamentale presentata nella forma della regola d'oro, esso è conosciuto in tutte le grandi religioni. Riferendosi al principio dell'amore, il Movimento propone una semplice metodologia del dialogo espressa nella cosidetta arte di amare, che indica quattro principali norme: amare tutti, amare per primi, amare come sè, farsi uno. L'arte di amare mette in evidenza la dialettica dell'amore cristiano, che sta nell' essere un dono per gli altri. Tale atteggiamento in genere richiama la reciprocità - condizione indispensabile per raggiungere l'unità. Il dialogo interreligioso che il Movimento conduce con i fedeli dell'ebrasimo, dell'islam, dell'induismo e del buddsimo si esprime nelle seguenti dimensioni: dialogo della vita (nasce dai contatti quotidiani con i fedeli di altre religioni); dialogo dell'agire (nella collaborazione in diverse sturutture internazionali ed interreligiose); dialogo degli esperti (tenuto dagli esperti di diverse religioni e tradizioni religiose) e dialogo delle esperienze religiose (lo scambio delle esperienze di vita secondo i libri sacri delle rispettive religioni). Tale dinamica del dialogo interreligioso, in sintonia con l'insegnamento conciliare espresso nel documento Nostra aetate, preserva dal sincretismo, porta alla scoperta delle radici della propria religione, ed anche di tutto ciò che la lega alle altre religioni e di conseguenza all'esperienza della fraternità universale. 